\title{
Possible Involvement of Photoperiodic Regulation in Reproductive Endocrine System of Female Olive Flounder Paralichthys olivaceus
}

\author{
Hyun Chul Kim, Chi Hoon Lee², Sung Pyu Hur², Byeong Hoon Kim², \\ Jun Young Park ${ }^{2}$ and ${ }^{\dagger}$ Young Don Lee ${ }^{2}$ \\ ${ }^{1}$ Genetics \& Breeding Research Center, National Fisheries Research \& Development Institute, Geoje 656-842, Korea \\ ${ }^{2}$ Marine Science Institute, Jeju National University, Jeju 695-965, Korea
}

\begin{abstract}
This study investigated possible involvement of photoperiodic regulation in reproductive endocrine system of female olive flounder. To investigate the influence on brain-pituitary axis in endocrine system by regulating photoperiod, compared expression level of Kisspeptin and sbGnRH mRNA in brain and FSH- $\beta$, LH- $\beta$ and GH mRNA in pituitary before and after spawning. Photoperiod was treated natural photoperiod and long photoperiod (15L:9D) conditions from Aug. 2013 to Jun. 2014. Continuous long photoperiod treatment from Aug. (post-spawning phase) was inhibited gonadal development of female olive flounder. In natural photoperiod group, the Kiss2 expression level a significant declined in Mar. (spawning period). And also, FSH- $\beta$, LH- $\beta$ and GH mRNA expression levels were increasing at this period. However, in long photoperiod group, hypothalamic Kiss2, FSH- $\beta$, LH- $\beta$ and GH mRNA expression levels did not show any significant fluctuation. These results suggest that expression of hypothalamic Kiss2, GtH and GH in the pituitary would change in response to photoperiod and their possible involvement of photoperiodic regulation in reproductive endocrine system of the BPG axis.
\end{abstract}

Key words : Photoperiodic regulation, Kisspeptin, FSH- $\beta$, LH- $\beta$, GH, Olive flounder

\section{INTRODUCTION}

The maturation and reproduction in fish are regulating by neuropeptide and sexual hormone in reproductive endocrine system of the BPG axis. This axis is effected on environmental factor, mainly photoperiod and water temperature (Migaud et al., 2010). The Kisspeptin2 (Kiss2) is stimulate the secretion of hypothalamic GnRH neurons and $\mathrm{GnRH}$ neurons are regulates the secretion of pituitary $\mathrm{GtH}$ (Roa et al., 2011). The gonadotropins, FSH and LH induces the synthesis of sex steroids in the gonad and activate gonadal development and maturation (Tena-Semperea, 2010; Mechaly et al., 2013). Interaction between reproduction and growth occurs in many vertebrates and is particularly closely linked during sexual maturation in fish (Le Gac et al., 1993). GH is synthesized in the somatotroph and gonadotrophs of pituitary gland. It is related to the somatic growth, reproduction, immunity, osmotic and ionic regulation in fish (Björnsson, 1997; Moriyama et al., 2000). The biological actions of $\mathrm{GH}$ are not restricted to growth promotion; instead they include gonadal development, appetite, and social behavior. GH system in endocrine network is

\footnotetext{
Manuscript received 11 December 2014, Received in revised form 27 December 2014, Accepted 3 February 2015

† Corresponding Author : Young-Don Lee, Marine Science Institute, Jeju National University, 19-5, Hamdeok 5(o)-gill, Jocheon, Jeju Special SelfGoverning Province 695-965, Korea. Tel. : +82-64-782-8922, Fax : +82-64-782-8281, E-mail : leemri@ jejunu.ac.kr

This is an Open Access article distributed under the terms of the Creative Commons Attribution Non-Commercial License (http:// creativecommons.org/licenses/by-nc/3.0) which permits unrestricted non-commercial use, distribution, and reproduction in any medium, provided the original work is properly cited.
} 
highly intricate, including many environmental factors appropriate for the diverse physiological circumstances in which $\mathrm{GH}$ is involved.

Generally, many fish are responsive to changes in photoperiod with alterations of growth rate and synchronizers of seasonal reproduction, which is generally directly related to day-length (Boeuf \& Le Bail, 1999; Falcon et al., 2010). Long photoperiods have been demonstrated to increase the growth rates of salmonids independent of temperature (Villarreal et al., 1988; Saunders et al., 1989; Leiner \& Mackenzie, 2001). These variations in growth and reproductive events suggest that light influences the secretion of brain-pituitary system in fish endocrine, such as growth hormone, Kisspeptin, GnRHs, and GtHs.

Olive flounder, Paralichthys olivaceus is economically important aquaculture fish in Korea. Although it is well established that maturation and spawning of olive flounder is induced by photoperiod manipulation (Min, 1988; Hur, 1991; Kim et al., 2013), the physiological mechanism in endocrine system is insufficient. Therefore, the present study investigated possible involvement of photoperiodic regulation on brain-pituitary axis in endocrine system of female olive flounder. In addition, real time qRT-PCR analysis compared expression level of Kiss2 and sbGnRH mRNA in hypothalamus and FSH- $\beta$, LH- $\beta$ and GH mRNA in pituitary before and after spawning.

\section{MATERIALS AND METHODS}

\section{Fish}

Olive flounder (total length $37-39 \mathrm{~cm}$, body weight 580 600 g) being reared at Hanchang Fishery Co. Ltd., located in Seogwipo, Jeju, South Korea, were examined. Based on previous study (Kim et al., 2013), the experimental fish were divided into two groups; the control group under a condition with natural photoperiod and the treatment group under an artificial condition with controlled photoperiod
(15L: 9D= light on 0600h). They were reared for approximately 11 months from August 2013 to June 2014. Seven to ten fish from each group were randomly selected to compare ovarian development and Kiss2, sbGnRH, GtHs and $\mathrm{GH}$ expression under different conditions for three times; one in December 2013 (Growth period), another in March 2014 (Spawning period), and the third in June 2014 (Spent period). The experimental fish were anesthetized with 2-phenoxyethanol (Sigma-Aldrich, St. Louis, Mo), then hypothalamus, pituitary and ovary were extracted. The extracted ovary of each specimen were weighted for calculation of the gonadosomatic index (GSI=gonad weight/ body weight $\times 100$ ). For the histological analysis, ovaries samples were fixed in Bouin's solution, embedded in paraffin, sectioned $5 \mu \mathrm{m}$ thickness and stained with haematoxylineosin. The hypothalamus and pituitary sample were kept at $-80^{\circ} \mathrm{C}$ until total RNA extraction.

\section{Total RNA extraction and cDNA synthesis}

The total amount of total RNA from the hypothalamus and pituitary samples was extracted using RNAiso Reagent (TaKaRa Bio, Kyoto, Japan). The total RNA was treated with RQ RNase-free DNase (Promega, Madison, WI) to prevent genomic DNA contamination. The hypothalamus and purity of the total extracted RNA from the pituitary was examined with the ratio of 1.87 and 2.01 for A260/ A280 ratio. From $1 \mu \mathrm{g}$ of the extracted total RNA, the reverse transcription reaction was performed to synthesize cDNA using the Transcriptor First strand cDNA Synthesis kit (Roche Diagnostics, Mannheim, Germany).

\section{Real-time qPCR (qPCR)}

Primers for the experiments were produced by Kiss2, sbGnRH, FSH- $\beta$, LH- $\beta$, and GH genes of P. olivaceus that are listed on NCBI databse (Table 1). A qPCR was conducted with $20 \mathrm{ng}$ of cDNA using SYBR green premix PCR kit (TaKaRa-Bio) in CFX96 ${ }^{\mathrm{TM}}$ Real-time System (Bio-Rad, 
Table 1. Primers used for amplification of QPCR

\begin{tabular}{cc}
\hline \hline Primers & Sequence \\
\hline Kiss2 F & 5'-TGTGGTGTGTGGCCTGATCGTC-3' \\
Kiss2 R & 5'-GTTGAATTTACTCCTGCGGTCGTTGC-3' \\
sbGnRH F & 5'-CTGTCAGCACTGGTCCTACG-3' \\
sbGnRH R & 5'-TAAGTTCTGCGTCCGTTCCC-3' \\
FSH- $\beta$ F & 5'-AGCTTCGACTGTCGTCCAAC-3' \\
FSH- $\beta$ R & 5'-CAGCACCGAGTACATCTCCA-3' \\
LH- $\beta$ F & 5'-CCGACGTGTCTTCTCATCAA-3' \\
LH- $\beta$ R & 5'-CGGTGTCTCTGGAGAAGGAG-3' \\
GH F & 5'-TGAGGACCCAGGTTACATCC-3' \\
GH R & 5'-GAGAATCCACCTGCTCCATC-3' \\
Ef1- $\alpha$ F & 5'-GCAGCTCATTGTTGGAGTCA-3' \\
Ef1- $\alpha$ R & 5'-ACACTTGCAGGGTTGTAGCC-3' \\
\hline
\end{tabular}

Hercules, CA). PCR was performed at $95^{\circ} \mathrm{C}$ after the initial denaturation. Afterwards, the PCR reaction was performed by 40 cycle of denaturation for $45 \mathrm{~s}$ at $94^{\circ} \mathrm{C}$, annealing for $45 \mathrm{~s}$ at $58^{\circ} \mathrm{C}$, and extension for $1 \mathrm{~min}$ at $72^{\circ} \mathrm{C}$. Expression of the Kiss2, sbGnRH, FSH- $\beta$, LH- $\beta$ and GH genes in each sample was normalized to the amount of the internal control EF1- $\alpha$ gene.

\section{Statistical analysis}

All data are presented as mean \pm standard error (SEM) and considered significantly different at $P<0.05$. Statistical analysis of data was analyzed by one-way ANOVA followed by Duncan's multiple range test using statistics 18.0 for windows (SPSS Inc.).

\section{RESULTS}

1. Change in the gonadosomatic index (GSI)

In December 2013, the GSI of natural condition and long photoperiod group was $1.29 \pm 0.10$ and $1.31 \pm 0.15$, respectively, showed no significant statistical difference.

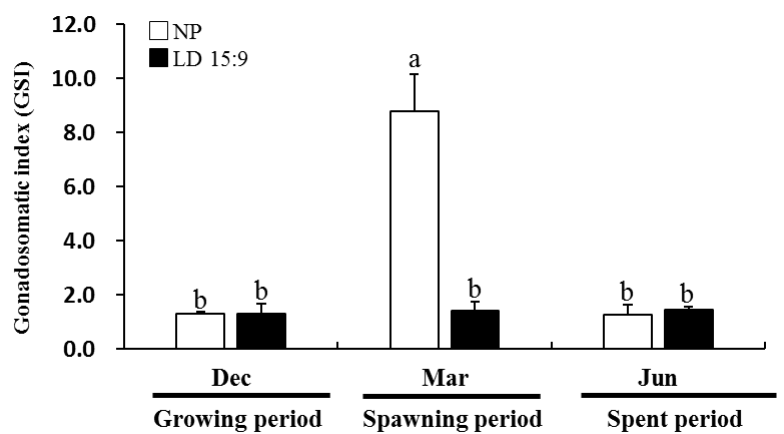

Fig. 1. Gonadosomatic index (GSI) in female Paralichthys olivaceus under different photoperiod conditions. NP, natural photoperiod; LD 15:9, long photoperiod 15L:9D. Values are mean \pm SEM. The signifycant difference are identified by the different low case letters $(P<0.05$ by Duncan's multiple range test).

However, in March 2014, GSI of natural condition showed drastically increased at $8.79 \pm 1.36$, showing a significantly difference $(P<0.05)($ Fig .1$)$.

\section{Gonadal development}

In December 2013, the ovaries of natural condition and long photoperiod group were growing phase, mainly contained oil-droplet stage oocytes of 80 to $150 \mu \mathrm{m}$ in diameter (Fig. 2A, B). In March 2014, the ovary of natural condition became mature as vitellogenic oocytes of 220 to $500 \mu \mathrm{m}$ in diameter (Fig. 2C). But the ovary of long photoperiod group were immature, mainly contained oil-droplet stage oocytes (Fig. 2D). In June 2014, the ovary of natural condition were spent phase, mainly contained peri-nucleolus stage oocytes and oil-droplet stage oocytes (Fig. 2E). The ovary of long photoperiod group were still growing phase, contained the oil-droplet stage oocytes (Fig. 2F).

3. The mRNA expression levels of Kiss2 and sbGnRH in the hypothalamus

In the natural condition, the expression levels of Kiss2 mRNA was significantly decreased at March 2014 than at December 2013 and June 2014. However, in the long 

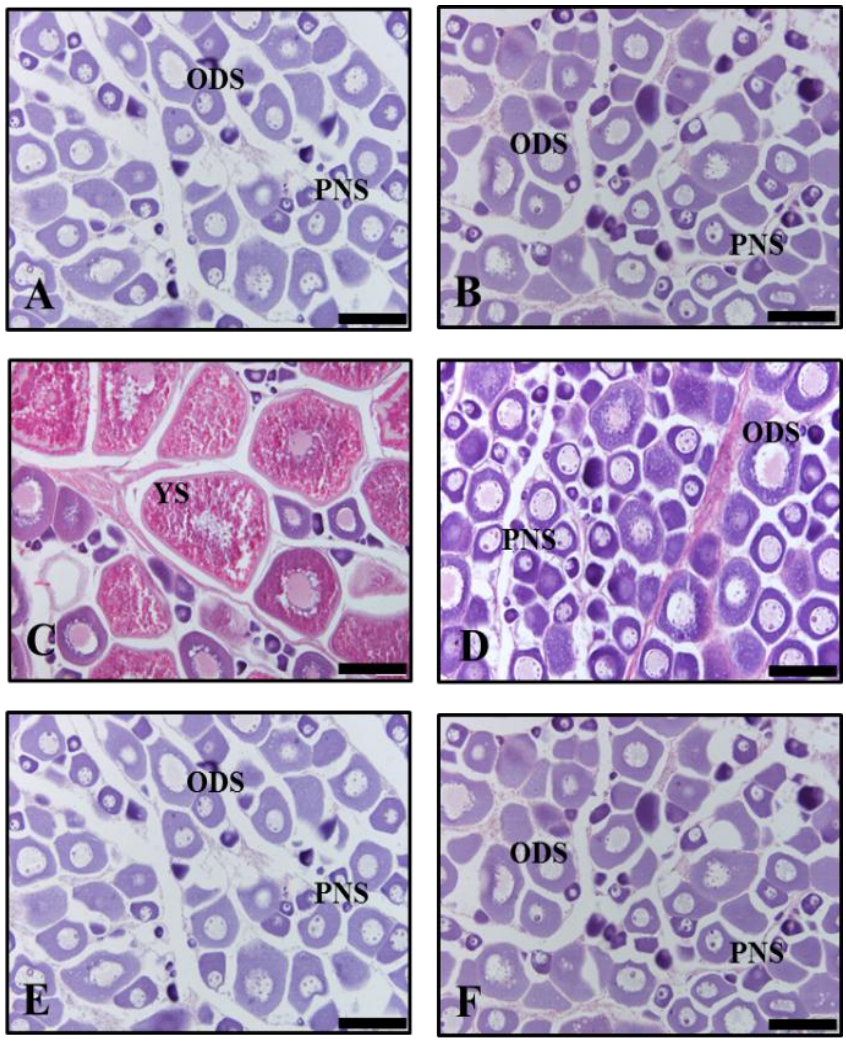

Fig. 2. Photomicrograph of ovarian development phases of Paralichthys olivaceus from December, 2013 to June, 2014. A, ovary of December 2013 under natural photoperiod (NP) condition; B, ovary of December 2013 under long photoperiod (LD 15:9) condition; C and E, ovary of March and June 2014 under NP condition; D and F, ovary of March and June 2014 under LD 15:9 condition. PNS, perinucleolus stage; ODS, oil-droplet stage; YS, Yolk stage. A to F scale bars indicate $200 \mu \mathrm{m}$.

photoperiod group, the expression levels of Kiss2 mRNA had no significant statistical difference during experimental periods (Fig. 3A). In the expression pattern of Kiss 2 mRNA of natural condition, non-significant increase of Kiss2 was observed between growth period and spent period, but its expression declined significantly during spawning period $(p<0.05)$.

The expression levels of sbGnRH mRNA of natural condition and long photoperiod group had no significantly difference throughout during the experiments (Fig. 3B).
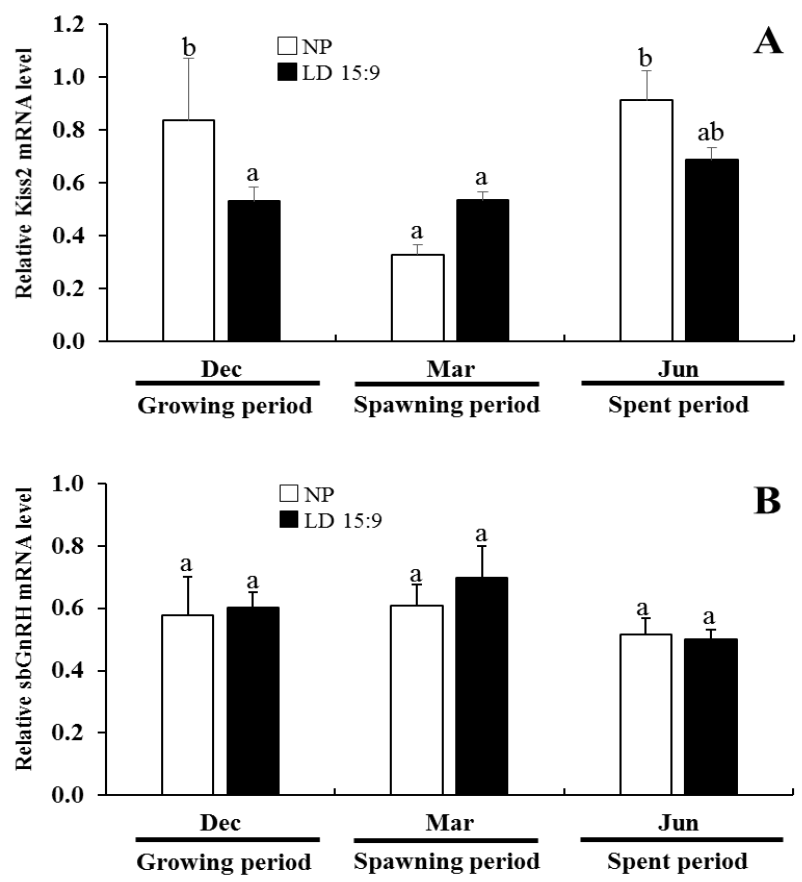

Fig. 3. Kiss2 and sbGnRH mRNA levels in the hypothalamus of female Paralichthys olivaceus under different photoperiod conditions. NP, natural photoperiod; LD 15:9, long photoperiod 15L:9D. Values are mean \pm SEM. The significant difference are identified by the different low case letters $(P<$ 0.05 by Duncan's multiple range test).

4. The mRNA expression of FSH- $\beta$, LH- $\beta$, and $\mathrm{GH}$ in pituitary

In the natural condition, the expression FSH- $\beta$ mRNA at the December showed lower levels. However, the March experiment showed drastically increased levels of FSH- $\beta$ mRNA determining significantly difference $(P<0.05)$. In June 2014, the FSH- $\beta$ mRNA expression were declined and reached low levels. In the long photoperiod group, the expression of FSH- $\beta$ mRNA at the December showed higher levels. And, FSH- $\beta$ mRNA expression level slightly declined from March to June, but the changes were not significant (Fig. 4A).

The LH- $\beta$ mRNA expression profile showed a similar pattern to that of FSH- $\beta$ mRNA expression levels. In the natural condition, the LH- $\beta$ mRNA showed lower levels. 

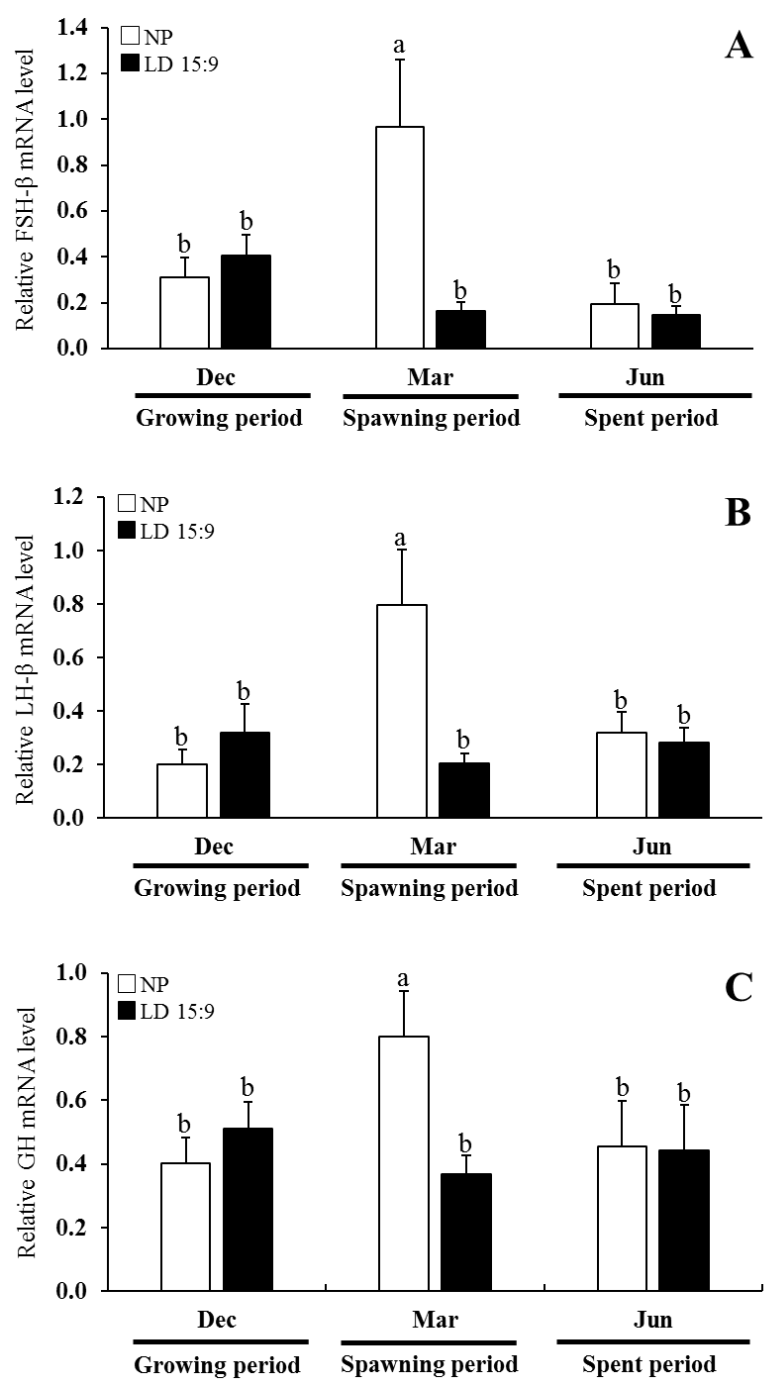

Fig. 4. FSH- $\beta$, LH- $\beta$ and GH mRNA levels in the pituitary of female Paralichthys olivaceus under differrent photoperiod conditions. NP, natural photoperiod; LD 15:9, long photoperiod 15L:9D. Values are mean \pm SEM. The significant difference are identified by the different low case letters $(P<0.05$ by Duncan's multiple range test).

During March, LH- $\beta$ mRNA expression increased signifycantly and reached higher levels $(p<0.05)$. In the long photoperiod group, the LH- $\beta$ mRNA showed lower levels throughout all of the experiments (Fig. 4B).

In the expression pattern GH mRNA of natural condition, the GH mRNA level drastically increased at March. In particular, levels were approximately 2 -fold higher than long photoperiod group. In the long photoperiod group, the expression of GH mRNA at the December showed higher levels. And, GH mRNA expression level slightly declined from March to June, but the changes were not significant (Fig. 4C).

\section{DISCUSSION}

In the present study, we investigated effects of artificial photoperiod manipulation on maturation of female olive flounder by reproductive endocrine system of the BPG axis. Firstly, we investigated effect ovarian development by long photoperiod manipulation using histological analyses, and compared expression level of Kiss2 and sbGnRH mRNA in hypothalamus and FSH- $\beta$, LH- $\beta$ and GH mRNA in pituitary before and after spawning.

In fish, gonadal maturation and reproduction is regulated by a complex network of BPG axis. This axis is effected on environmental factor, mainly photoperiod and water temperature (Migaud et al., 2010). In Eurasian perch, 24-h photophase inhibit the initiation of gametogenesis and plasma testosterone and estradiol-17 $\beta$ levels were lower than in fish from the natural treatment. In particular, water temperature is not the only essential factor in the reproduction timing of this species (Migaud et al., 2004). Gilthead seabream, Sparus aurata, that spawns in the winter, also showed low GSI when treated under long photoperiod of 15.5L:8.5D until the spawning season (Kissil et al., 2001). In a previous study, we confirmed that long photoperiodic conditions regulates sex maturation of olive flounder (Kim et al., 2013). In this study, continuous long photoperiod (15L:9D) treatment from August (post-spawning phase) was inhibited gonadal development of female olive flounder.

The external cues stimulate hypothalamic neuropeptide of the brain and the neuropeptide as a kisspeptin and $\mathrm{GnRH}$ are regulates the secretion of pituitary GtH (FSH and $\mathrm{LH}$ ), which in turn activate gonadal development and maturation (Tena-Semperea, 2010; Mechaly et al., 2013). 
The two kisspeptin genes in fish have revealed the presence of Kiss1 and Kiss2 (Felip et al., 2009). These genes are potential regulators of reproduction and stimulates the release of GnRH (Kitahashi et al., 2009) and regulated by environmental factors such as photoperiods, steroid hormones, metabolic signals and stress (Parhar et al., 2012). In the chub mackerel, during late spermatogenesis and early vitellogenesis, Kiss2 levels increased slightly, followed by a significant decline during spermiation or late vitellogenesis in males or females, respectively (Selvaraj et al., 2010). The Kiss1 receptor mRNA expression was lower during advanced stages of spermatogenesis in the fathead minnow (Filby et al., 2008) and oogenesis in the grey mullet (Nocillado et al., 2007). In this study, the Kiss2 expression level a significant declined in March (spawning period), and GtH level significantly increased at this season in natural photoperiod group. However, in long photoperiod group, the Kiss2 and GtH expression level had no significant statistical difference throughout all of the experiment.

The somatogenic and gonadotropic axes have been known to be closely linked during growth and sexual maturation in fish. GH is produced and secreted anterior pituitary, is regulated by neuroendocrine factors from the hypothalamus. GH is directly regulated somatic growth (Moriyama et al., 2000) and it's related to the other physiological functions of fish such as reproduction, immunity, osmotic and ionic regulation (Björnsson, 1997). In hypophysectomized male and female killifish, treatment with recombinant salmon GH prevents gonadal regression and stimulates testosterone and estradiol production (Singh et al., 1988). In the mechanism of GH stimulatory action on steroidogenesis using ovarian tissue of spotted seatrout, GH is stimulated ovarian aromatase activity (Singh \& Thomas, 1993). GH can potentiate GtH-II stimulated steroidogenesis (Trudeau, 1997). In this study, FSH- $\beta$, LH- $\beta$ and GH mRNA expression levels increased during spawning period in natural photoperiod group. However, in the long photoperiod group, FSH- $\beta$,
LH- $\beta$ and GH mRNA expression levels did not show any significant fluctuation.

In conclusion, artificially exposed long photoperiod regulated kiss $2 \mathrm{mRNA}$ in the hypothalamus during spawning periods. Further, FSH- $\beta$, LH- $\beta$ and GH mRNA expression levels in pituitary were found to fluctuate during spawning season. These results suggest that expression of the neuroKisspeptin in the hypothalamus, GtH and $\mathrm{GH}$ in the pituitary would change in response to photoperiod and their possible involvement of photoperiodic regulation in reproductive endocrine system of the BPG axis.

\section{ACKNOWLEDGEMENTS}

This research was supported by the National Fisheries Research and Development Institute (RP-2015-AQ-020) grant.

\section{REFERENCES}

Björnsson BTH (1997) The biology of salmon growth hormone: from daylight to dominance. Fish Physiol Biochem 17:9-24. Boeuf G, Le Bail PY (1999). Does light have and influence on fish growth? Aquaculture 177:129-152.

Falcon J, Migaud H, Muñoz-Cueto JA, Carrillo M (2010) Current knowledge on the melatonin system in teleost fish. Gen Comp Endocrinol 165:465-82.

Felip A, Zanuy S, Pineda R, Pinilla L, Carrillo M, TenaSempere M, Gómez A (2009). Evidence for two distinct KiSS genes in non-placental vertebrates that encode kisspeptins with different gonadotropin-releasing activities in fish and mammals. Mol Cell Endocrinol 312:61-71.

Filby AL, van Aerle R, Duitman J, Tyler CR (2008) The kisspeptin/gonadotropin releasing hormone pathway and molecular signaling of puberty in fish. Biol Reprod 78: 278-289.

Hur SB (1991) Spawning inducement of flounder, Paralichthys olivaceus by the control of water temperature and photoperiod. J Aquaculture 4:85-95. 
Kim BH, Lee CH, Hur SW, Hur SP, Kim DH, Suh HL, Kim SY, Lee YD (2013) Long photoperiod affects gonadal development in olive flounder Paralichthys olivaceus. Dev Reprod 17:241-246.

Kissil GW, Lupatsch I, Elizur A, Zohar Y (2001) Long photoperiod delayed spawning and increased somatic growth in gilthead seabream (Sparus aurata). Aquaculture 200:363-379.

Kitahashi T, Ogawa S, Parhar IS (2009) Cloning and expression of kiss 2 in the Zebrafish and Medaka. Endocrinology 150:821-831.

Le Gac F, Blaise O, Fostier A, Le Bail, PY, Loir M, Mourot B, Weil C (1993) Growth hormone (GH) and reproduction: a review. Fish Physiol Biochem 11:219-232.

Leiner KA, Mackenzie DS (2001) The effects of photoperiod on growth rate and circulation thyroid hormone levels in the red drum, Sciaenops ocellatus: evidence for a free-running circadian rhythm of T4 secretion. Comp Biochem Physiol 130:141-149.

Mechaly AS, Vinas J, Piferrer F (2013) The kisspeptin system genes in teleost fish, their structure and regulation, with particular attention to the situation in Pleuronectiformes. Gen Comp Endocrinol 188:258-268.

Migaud H, Davie A, Taylor JF (2010) Current knowledge on the photoneuroendocrime regulation of reproduction in temperate fish species. J Fish Biol 76:27-68.

Migaud H, Fontaine P, Kestemont P, Wang N, Brun-Bellut $\mathrm{J}$ (2004) Influence of photoperiod on the onset of gonadogenesis in Eurasian perch Perca fluviatilis. Aquaculture 214:561-574.

Min BS (1988) Maturation spawning of flounder (Paralichthys olivaceus) under captive conditions. J Aquaculture 1:25-39.

Moriyama S, Ayson FG, Kawauchi H (2000) Growth regulation by insulin-like growth factor-I in fish. Biosci Biotechnol Biochem 64:1553-1562.

Nocillado JN, Levavi-Sivan B, Carrick F, Elizur A (2007) Temporal expression of G-protein-coupled receptor 54
(GPR54), gonadotropin releasing hormones (GnRH), and dopamine receptor D2 (drd2) in pubertal female grey mullet, Mugil cephalus. Gen Comp Endocrinol 150:278-287.

Parhar IS, Ogawa S, Kitahashi T (2012) RFamide peptides as mediators in environmental control of $\mathrm{GnRH}$ neurons. Progress in Neurobiology 98:176-196.

Roa J, Navarro TM, Tena-Sempere M (2011). Kisspeptins in reproductive biology: Consensus knowledge and recent developments. Biol Reprod 85:650-660.

Saunders RL, Specker JL, Komourdjian MP (1989) Effects of photoperiod on growth and smolting in juvenile Atlantic salmon (Salmo salar). Aquaculture 82:103-117.

Selvaraj S, Kitano H, Fujinaga Y, Ohga H, Yoneda M, Yamaguchi A, Shimizu A, Matsuyama M (2010). Molecular characterization, tissue distribution, and mRNA expression profiles of two Kiss genes in the adult male and female chub markerel (Scomber japonicas) during different gonadal stages. Gen Comp Endocrinol 169:28-38.

Singh H, Griffith RW, Takahashi A, Kawauchi H, Thomas P, Stegeman JJ (1988). Regulation of gonadal steroidgenesis in Fundulus heteroclitus by recombinant salmon growth hormone and prolactin. Gen Comp Endocrinol 72:144-153.

Singh H, Tomas P (1993) Mechanism of stimulatory action of growth hormone on ovarian steroidogenesis in spotted seatrout, Cynoscion nebulosus. Gen Comp Endocrinol 89:341-353.

Tena-Semperea M (2010) Kisspeptin signaling in the brain: Recent developments and future challenges. Mol Cell Endocrinol 314:164-169.

Trudeau VL (1997) Neuroendocrine regulation of gonadotrophin II release and gonadal growth in the goldfish Carassius auratus. Rev Reprod 2:55-68.

Villarreal CA, Thorpe JE, Miles MS (1988) Influence of photoperiod on growth changes in juvenile Atlantic salmon, Salmon salar L. J Fish Biol 33:15-30. 